\title{
Wybrane aspekty stosunków pomiędzy Polską a Wielką Brytanią w zakresie opodatkowania dochodów osób fizycznych
}

\section{Wprowadzenie}

Stosunki między Rzecząpospolitą Polską a Zjednoczonym Królestwem Wielkiej Brytanii i Irlandii Północnej ${ }^{1}$ w zakresie podatków dochodowych dotyczą stanowienia i stosowania prawa podatkowego ${ }^{2}$. Ich podmiotami są: władza ustawodawcza ${ }^{3}$, sądownicza i wykonawcza, w tym organy administracji finansowej ${ }^{4}$. Stosunki te dotyczą materialnego i proceduralnego prawa podatkowego i są kształtowane na gruncie prawa: międzynarodowego, unijnego i krajowego ${ }^{5}$. Są one nawiązywane i realizowane w celu dążenia do skutecznego poboru podatków, eliminacji podwójnego opodatkowania oraz zapobieżenia unikaniu i uchylaniu się od opodatkowania ${ }^{6}$. Niniejsze opracowanie dotyczy głównie stosunków na gruncie stosowania proceduralnego prawa podatkowego.

* Mgr Paweł Klimek - Katedra Prawa Finansowego, Wydział Prawa, Administracji i Stosunków Międzynarodowych, Krakowska Akademia im. Andrzeja Frycza Modrzewskiego.

${ }^{1}$ Dalej: Wielka Brytania.

2 D. Mączyński, Międzynarodowa wspótpraca w sprawach podatkowych, Warszawa 2009, s. 23.

${ }^{3}$ Należy pamiętać, że kierunek tym stosunkom nadają także polscy przedstawiciele w Organisation for Economic Co-operation and Development (Organizacji Współpracy Gospodarczej i Rozwoju - OECD) i organach stanowiących Unii Europejskiej.

${ }^{4}$ Pojęcie to jest szersze od administracji podatkowej. Oznacza wszelkie organy administracji załatwiające sprawy podatkowe, uczestniczące we wszystkich fazach postępowania podatkowego - wymiarze, czynnościach sprawdzających, kontroli i egzekucji.

${ }^{5}$ K. Koperkiewicz-Mordel, W. Chróścielewski, W. Nykiel, Polskie prawo podatkowe, Warszawa 2006, s. 279-285.

${ }^{6}$ Unikanie opodatkowania (tax avoidance) jest redukcją obciążeń podatkowych przy pomocy metod i środków dozwolonych przez prawo podatkowe, a uchylanie się od opodatkowania (tax evasion) - ich redukcją przy zastosowaniu metod i środków nielegalnych. E. Martin, J. Law (red.), Dictionary of Law, Oxford 2006, s. 527-528. 


\section{Stosunki na gruncie prawa międzynarodowego}

Polska (od 1996 r.) i Wielka Brytania (od 1961 r.) są członkami OECD7, omawiane stosunki nawiązują i realizują więc m.in. w oparciu o Modelową konwencję podatkową w zakresie podatków od dochodu i kapitału z 1992 r. ${ }^{8}$ Dla stosunków pomiędzy Polską a terytoriami stowarzyszonymi i zależnymi Wielkiej Brytanii znaczenie ma przede wszystkim Modelowe porozumienie o wymianie informacji w sprawach podatkowych OECD z dnia 18 kwietnia 2002 r., na podstawie którego zawarte zostały umowy o wymianie informacji w sprawach podatkowych z Guernsey, Jersey i Wyspą Man. Mniejsze znaczenie dla omawianych stosunków ma Konwencja o wzajemnej pomocy administracyjnej w sprawach podatkowych z dnia 25 stycznia 1988 r. $^{10}$, zawarta pod auspicjami Rady Europy i OECD.

Konwencja Modelowa OECD jako akt wzorcowy nie zawiera wiążących norm prawa międzynarodowego, ma jednak znaczenie dla treści zawartej umowy bilateralnej i jej interpretacji ${ }^{11}$. Albowiem konwencja ta i Komentarz do niej dla Polski i Wielkiej Brytanii są częścią kontekstu umowy międzynarodowej w świetle art. 31 ust. 1 Konwencji wiedeńskiej z dnia 23 maja 1969 r. o prawie traktatów ${ }^{12}$. Ponadto, państwa członkowskie OECD muszą stosować wzorzec, chyba że jedno z nich zgłosiło zastrzeżenia lub ma szczególne powody ${ }^{13}$.

Modelowa Konwencja OECD z 1992 r. w przeciwieństwie do wersji z lat 1966 i 1977 została wydana na wymiennych kartach umożliwiających jej okresową rewizję ${ }^{14}$. Ostatnia, ósma wersja skrócona konwencji pochodzi z $2010 \mathrm{r}$. Komentarz do konwencji również podlega okresowemu uaktualnieniu, a OECD zaleca stosowanie jego aktualnej wersji $1^{15}$.

Wzorcem dla Konwencji między Rzecząpospolitą Polską a Zjednoczonym Królestwem Wielkiej Brytanii i Irlandii Północnej w sprawie unikania podwójnego opodatkowania w zakresie podatków od dochodu i od zysków majątkowych ${ }^{16}$ była wersja po rewizji z 2005 r., która odbiega częściowo od obecnego wzorca.

\footnotetext{
${ }^{7}$ Powstałej w 1961 r. w Paryżu na mocy Konwencji o Organizacji Współpracy Gospodarczej i Rozwoju, podpisanej dnia 14 grudnia 1960 r. (Dz. U. z 1998 r. Nr 76, poz. 490).

8 Dalej: Konwencja Modelowa OECD.

9 Dz. U. z 2012 r. poz. 615; Dz. U. z 2012 r. poz. 618; Dz. U. z 2011 r. Nr 283, poz. 1665.

${ }^{10}$ Dz. U. z 1998 r. Nr 141, poz. 913 i 914 (dalej: Konwencja o pomocy administracyjnej).

${ }^{11}$ D. Mączyński, op. cit., s. 31.

${ }^{12}$ Dz. U. z 1990 r. Nr 74, poz. 439 (dalej: Konwencja wiedeńska). Zob. K. Bany, Znaczenie Komentarza do Modelowej Konwencji OECD o unikaniu podwójnego opodatkowania, „Przegląd Podatkowy" 2000, nr 12, s. 27.

${ }^{13} \mathrm{~K}$. Bany, Interpretacja dwustronnych konwencji o unikaniu podwójnego opodatkowania (1), „Przegląd Podatkowy” 2005, nr 6, s. 24.

${ }^{14} \mathrm{H}$. Hamaekers i in., Wprowadzenie do międzynarodowego prawa podatkowego, Warszawa 2006, s. 152.

15 OECD, Modelowa konwencja w sprawie podatku od dochodu i majątku - wersja skrócona-lipiec 2010, Warszawa 2011, s. 19, pkt 35 i 36.

16 Dz. U. Nr 250, poz. 1840 (dalej: Konwencja bilateralna).
} 
Konwencja wiedeńska stanowi, iż podpisanie umowy zobowiązuje państwo do rozpoczęcia procedury ratyfikacyjnej, która nie musi zostać zakończona, a państwo nie jest związane umową $\mathrm{w}$ trakcie ratyfikacji ${ }^{17}$. Umowy międzynarodowe wywierają bowiem skutek bezpośredni (umowa staje się częścią prawa krajowego - warunkowo lub bezwarunkowo) albo skutek pośredni (umowa wymaga implementacji do prawa krajowego ${ }^{18}$.

Zgodnie z art. 91 ust. 2 Konstytucji Rzeczypospolitej Polskiej z dnia 2 kwietnia 1997 r. ${ }^{19}$ Konwencja bilateralna jest źródłem prawa powszechnie obowiązującego i jest stosowana przed normami ustaw krajowych z uwagi na jej ratyfikację za uprzednią zgodą wyrażoną w ustawie (art. 87 ust. 1 Konstytucji). Natomiast w Wielkiej Brytanii umowy międzynarodowe podlegają implementacji do prawa krajowego ${ }^{20}$.

W przypadku osób fizycznych Konwencja bilateralna ma zastosowanie w Polsce do podatku dochodowego od osób fizycznych ${ }^{21}$ od dnia 1 stycznia 2007 r., a w Wielkiej Brytanii do income tax ${ }^{22}$ od dnia 6 kwietnia 2007 r. oraz capital gains tax $^{23}$ od dnia 1 kwietnia $2007 \mathrm{r}$. Konwencję należy więc stosować do dochodów bądź zysków kapitałowych osiągniętych po wspomnianych datach.

Najistotniejszym narzędziem rozwiązania problemów interpretacyjnych omawianej Konwencji jest jej art. 25, regulujący procedurę wzajemnego porozumiewania, która nie obliguje jednak stron do osiągnięcia ostatecznego porozumienia. Art. 26 dotyczy wymiany informacji pomiędzy państwami. W Konwencji bilateralnej nie zawarto procedury dotyczącej pomocy w poborze podatków (której uregulowanie zaleca art. 27 Konwencji Modelowej OECD). Forma ta podlega jednak stosowaniu pomiędzy Polską a Wielką Brytanią w oparciu o regulacje unijne.

Art. 25 Konwencji bilateralnej zobowiązuje strony do dążenia do rozwiązania sytuacji, w której podatnik jest poddawany opodatkowaniu niezgodnemu $\mathrm{z}$ umową i zawiera sposoby osiągania porozumienia. W Konwencji bilateralnej brak jednak możliwości skierowania sprawy do arbitrażu (przewidzianej w art. 25

17 A. Amatucci (red.), International Tax Law, Alphen aan den Rijn 2006, s. 154.

${ }^{18}$ K. Bany, Interpretacja dwustronnych konwencji..., s. 21.

19 Dz. U. z 1997 r. Nr 78, poz. 483 (dalej: Konstytucja).

20 A. Aust, Modern Treaty Law and Practice, Cambridge 2000, s. 150.

${ }^{21}$ Regulowanego ustawą z dnia 26 lipca 1991 r. o podatku dochodowym od osób fizycznych (t.j. Dz. U. z 2010 r. Nr 51, poz. 307 ze zm.) (dalej: ustawa o podatku dochodowym).

${ }^{22}$ Będącego odpowiednikiem podatku dochodowego od osób fizycznych, regulowanego w Income and Corporation Taxes Act (1988 c. 1), Income Tax (Earnings and Pensions) Act (2003 c. 1), Income Tax (Trading and Other Income) Act (2005 c. 5) oraz Income Tax Act (2007 c. 3), a także w szeregu instrumentów statutowych (Statutory Instruments) wydawanych Przez Urząd Skarbu i Ceł Jej Królewskiej Mości (Her Majsty's Revenue and Customs) mających podobny charakter do polskich rozporządzeń. Wszystkie brytyjskie akty prawne dostępne są na stronie internetowej: www.legislation.gov.uk.

${ }^{23}$ Podatku od zysków kapitałowych, regulowanego w Taxation of Chargeable Gains Act (1992 c. 12). 
ust. 5 Konwencji Modelowej OECD). Gdy opodatkowanie ma miejsce w wyniku błędu popełnionego przez obie strony Konwencji bilateralnej, podatnik może żądać wszczęcia procedury wzajemnego porozumiewania się bez rezygnacji z krajowych środków ochrony, z których może wyłącznie korzystać, jeżeli błąd popełniły tylko organy jednego państwa ${ }^{24}$.

Procedura ta może być wszczęta przez rezydenta danego państwa, a wyjątkowo przez obywatela w zakresie dyskryminującego traktowania, przed jego organami, bez względu na fakt pobrania podatku, a wniesienie skargi musi nastąpić w ciągu trzech lat od uzyskania informacji o podjęciu działania skutkującego opodatkowaniem niezgodnym $\mathrm{z}$ umową ${ }^{25}$. Wyczerpanie toku instancyjnego prawa krajowego nie uniemożliwia skorzystania z procedury. Należy pamiętać, że normy prawa krajowego nie usprawiedliwiają naruszenia norm umów międzynarodowych ${ }^{26}$, dlatego po zastosowaniu wspomnianej procedury państwo powinno doprowadzić sytuację podatnika do stanu zgodnego z Konwencją bilateralną.

Art. 26 Konwencji bilateralnej stanowi, iż przekazywane informacje stanowią tajemnicę, tak jak informacje uzyskane zgodnie z prawem krajowym państwa je otrzymującego. Informacje dotyczą wszystkich podatków bez względu na ich rodzaj i nazwę, a także danych w posiadaniu banków i innych instytucji finansowych.

Przekazaniu podlegają wyłącznie informacje istotne i niemożliwe do uzyskania w krajowym postępowaniu podatkowym. Warunek istotności uniemożliwia państwom prowadzenia tzw. ekspedycji połowowych (fishig expeditions) służących uzyskaniu informacji niezwiązanych z konkretnym postępowaniem w celu uzyskania informacji, które mogą służyć wszczęciu postępowania ${ }^{27}$.

Konwencja bilateralna reguluje pięć form wymiany informacji: na żądanie, automatyczną, spontaniczną, dotyczącą całego sektora gospodarki i równoczesne kontrole podatkowe. Informacja na żądanie ma miejsce, gdy państwo prosi o konkretną informację. Automatyczna dotyczy informacji typowych, dotyczących wielu spraw tego samego rodzaju. Spontaniczna ma miejsce, gdy państwo przekazuje informacje drugiemu bez wniosku o ich przekazanie.

Jeżeli chodzi o możliwość odmowy udzielenia informacji, to należy pamiętać, iż państwo nie jest zobowiązane do stosowania środków nieprzewidzianych w prawie krajowym lub wewnętrznej praktyce administracyjnej i nie jest zobligowane do udzielenia informacji, której nie mogłoby uzyskać na podstawie prawa krajowego. Nie ma również obowiązku przekazywania informacji ujawniającej tajemnicę handlową, gospodarczą, przemysłową, kupiecką lub zawodową albo działalność handlową, a także informacji sprzecznych z porządkiem publicznym.

Stronami Konwencji o pomocy administracyjnej są zarówno Polska, jak i Wielka Brytania (nie dotyczy ona brytyjskich terytoriów zamorskich). Jednak

${ }^{24}$ OECD, Modelowa konwencja w sprawie podatku ..., s. 437-438, pkt 7 i 8.

${ }_{25}$ Ibidem, s. 439 i 441, pkt 14 i 16.

${ }^{26}$ Art. 27 Konwencji wiedeńskiej.

27 D. Mączyński, op. cit., s. 150. 
zgodnie z jej art. 27 ust. 2 państwa członkowskie Unii Europejskiej są zobowiązane stosować w ich wzajemnych stosunkach normy prawa unijnego bez względu na ich brzmienie. Konwencja ta pokrywa się w znaczącym zakresie z materią regulowaną przez prawo unijne, dotyczy bowiem: czynności organów administracji finansowej, takich jak określenie, ustalenie i pobór oraz egzekucja podatków, postępowanie przed organami administracyjnymi, w tym stosowanie kar administracyjnych oraz działanie w celu przygotowania postępowania karnego w sprawach podatkowych przed organami sądowymi - znajduje więc zastosowanie w omawianych stosunkach w niezwykle ograniczonym zakresie.

\section{Stosunki pomiędzy Polską a Wielką Brytanią a prawo unijne}

Unia Europejska została powołana dla wdrożenia swobody przepływu osób, towarów, usług i kapitału, m.in. poprzez zniesienie granic fiskalnych i harmonizację krajowych systemów podatkowych. Dlatego też analizowane stosunki podlegają regulacji na gruncie prawa unijnego.

Prawo unijne, zgodnie z orzecznictwem Europejskiego Trybunału Sprawiedliwości (ETS), podlega stosowaniu przed prawem krajowym ${ }^{28}$, a organy stosujące prawo podatkowe powinny pomijać prawo krajowe w przypadku jego kolizji z prawem unijnym ${ }^{29}$. W przypadku kolizji prawa międzynarodowego i prawa unijnego pominięciu podlega prawo międzynarodowe ${ }^{30}$.

O ile stosunki pomiędzy Polską a Wielką Brytanią na gruncie prawa unijnego w zakresie podatków pośrednich podlegają regulacji głównie za pomocą bezpośrednio stosowanych rozporządzeń, o tyle stosunki te w zakresie podatków bezpośrednich regulują głównie dyrektywy podlegające implementacji, jedno rozporządzenie i jedna konwencja międzynarodowa zawarta między państwami członkowskimi ${ }^{31}$.

${ }^{28}$ Wyrok ETS z dnia 5 lutego 1963 r., C-26/62; wyrok ETS z dnia 15 lipca 1964 r., C-6/64.

29 Art. 91 ust. 3 Konstytucji.

${ }^{30}$ Wyrok ETS z dnia 27 lutego 1962 r., C-10/61.

31 Dyrektywa Rady z dnia 19 grudnia 1977 r., 77/779 dotycząca wzajemnej pomocy właściwych władz Państw Członkowskich w dziedzinie podatków bezpośrednich (Dz. Urz. UE L z 1988 r., 336/15-20) (dalej: dyrektywa 77/799); dyrektywa Rady z dnia 3 czerwca 2003 r., 2003/48/ WE w sprawie opodatkowania dochodów z oszczędności w formie wpłacanych odsetek (Dz. Urz. UE L 157/38-48) (dalej: dyrektywa 2003/48); dyrektywa Rady 2008/55/WE z dnia 26 maja 2008 r. w sprawie wzajemnej pomocy przy odzyskiwaniu wierzytelności dotyczących niektórych opłat, ceł, podatków i innych obciążeń (t.j. Dz. Urz. UE L 150/28-38) (dalej: dyrektywa 2008/55); rozporządzenie Komisji 1179/2008/WE z dnia 28 listopada 2008 r. ustalające szczegółowe zasady wdrożenia niektórych przepisów dyrektywy Rady 2008/55/WE w sprawie wzajemnej pomocy przy dochodzeniu należności pieniężnych z tytułu niektórych opłat, ceł, podatków i innych obciążeń (Dz. Urz. UE L 319/21) (dalej: rozporządzenie 1179/2008); Konwencja z dnia 23 lipca 1990 r. w sprawie eliminowania podwójnego opodatkowania w przypadku korekty zysków przedsiębiorstw powiązanych (Dz. Urz. UE L 225/10-24 oraz Dz. U. z 2007 r. Nr 152, poz. 1080) (dalej: Konwencja arbitrażowa). 
Dyrektywa 77/799 modyfikuje i poszerza rozwiązania art. 26 Konwencji Modelowej OECD ${ }^{32}$. Zobowiązuje państwa członkowskie do przekazywania informacji, które mogą umożliwić prawidłowe naliczenia podatków od dochodu, kapitału i ustanowienia podatków od składek ubezpieczeniowych oraz zawiera wyliczenie podatków, do których jest stosowana (art. 1). Zgodnie jednak z wyrokiem ETS z dnia 11 października $2007 \mathrm{r}^{33}$ dyrektywa ta znajduje zastosowanie do wszelkich podatków mających charakter podobny.

Wyróżnia ona sześć form współpracy: wymianę informacji (na wniosek - art. 2, automatyczną - art. 3, spontaniczną - art. 4), obecność przedstawicieli jednego państwa w siedzibie władz innego państwa - art. 6, notyfikację - art. 8a i równoczesne kontrole - art. $8 \mathrm{~b}$.

Wymiana informacji na wniosek może mieć miejsce dopiero po wyczerpaniu krajowych źródeł informacji. Wymiana automatyczna dotyczy spraw, które państwa określiły w ramach procedury konsultacyjnej (art. 9). W przypadku wymiany spontanicznej państwo nie ma obowiązku przeprowadzania odrębnego postępowania dla uzyskania informacji. Jest jednak zobligowane, co niezwykle istotne, do udzielenia informacji, jeżeli: ma podstawy do przypuszczenia, że może dojść do zmniejszenia podatku w drugim państwie członkowskim; podatnik uzyskuje ulgę lub zwolnienie podatkowe, które może skutkować podwyższeniem podatku w drugim państwie; kontakty gospodarcze podatnika z podatnikiem innego państwa prowadzą do oszczędności podatkowej lub organ przypuszcza, że oszczędność podatkowa jest możliwa poprzez fikcyjny transfer zysków wewnątrz grupy przedsiębiorstw. Przyczyny odmowy udzielenia informacji reguluje art. 8 dyrektywy 77/799 i kształtują się one analogicznie do rozwiązań przewidzianych przez Konwencję Modelową OECD.

Obecność przedstawiciela jednego państwa w siedzibie drugiego państwa może mieć miejsce, jeżeli możliwość taką przewidziano w ramach procedury konsultacyjnej. Notyfikacja dotyczy „wszystkich instrumentów i decyzji, które pochodzą od władz administracyjnych żądającego państwa członkowskiego i dotyczą zastosowania na jego terytorium ustawodawstwa podatkowego objętego dyrektywą" (art. 8a) oraz ma na celu powiadomienie adresata o treści korespondencji mimo skutecznego doręczenia w świetle prawa krajowego. Art. 7 dyrektywy 77/799 nakłada na państwa obowiązek zachowania tajemnicy w zakresie analogicznym do Konwencji Modelowej OECD.

Procedura konsultacyjna $\mathrm{z}$ art. 9 dyrektywy jest podobna do procedury wzajemnego porozumiewania się, z tym że konsultacje te mogą odbywać się dwustronnie albo wielostronnie.

${ }^{32}$ G. Kofler, M. Tumpel, Double Taxation Conventions and European Directives in the Direct Tax Area, [w:] M. Lang, J. Schuch, C. Staringer, Tax Treaty Law and EC Law, Wiedeń 2007, s. 198. Dyrektywa ta podlega jednak uchyleniu z dniem 1 stycznia 2013 r. z uwagi na art. 28 dyrektywy Rady 2011/16/UE z dnia 15 lutego 2011 r. w sprawie współpracy administracyjnej w dziedzinie opodatkowania i uchylającej dyrektywę 77/799/EWG (Dz. Urz. UE L 64/1).

${ }^{33} \mathrm{C}-451 / 05$. 
Konwencja arbitrażowa służy eliminowaniu podwójnego opodatkowania w znaczeniu ekonomicznym - czyli wielokrotnego opodatkowania tego samego dochodu bez względu na podmiot go uzyskujący ${ }^{34}$. Została podpisana 23 lipca 1990 r. i weszła w życie 1 stycznia 1995 r. Konwencja została opatrzona instytucją analogiczną do komentarzy OECD - Kodeksem postępowania wspierającego skuteczne wykonanie konwencji w sprawie unikania podwójnego opodatkowania w przypadku korekty zysków przedsiębiorstw powiązanych ${ }^{35}$. Dotyczy ona wyłącznie podatków dochodowych enumeratywnie w niej wyliczonych (art. 2) i podlega stosowaniu w przypadku zastosowania cen transferowych w transakcjach dokonywanych przez przedsiębiorstwa powiązane, gdy dochód podlegający opodatkowaniu uzyskany przez jedno z tych przedsiębiorstw zostanie zaniżony w porównaniu z tym, który mógłby zostać uzyskany lub nie zostanie uzyskany w ogóle, co będzie skutkowało korektą podstawy opodatkowania i korekta ta zostanie dokonana przez jedno państwo członkowskie względem przedsiębiorstwa mającego siedzibę w innym państwie członkowskim (art. 1).

Przedsiębiorstwa są przedsiębiorstwami powiązanymi, jeżeli jedno z nich ma udział w zarządzaniu, kontroli lub kapitale drugiego lub te same osoby mają bezpośredni lub pośredni udział w zarządzaniu, kontroli lub kapitale jednego i drugiego przedsiębiorstwa.

Dyrektywa 2003/48 dotyczy opodatkowania dochodów w postaci odsetek. Właścicielem odsetek jest osoba, której wypłacane są odsetki, chyba że udowodni, iż działa jako podmiot wypłacający i ujawni tożsamość osoby, na rzecz której je wypłaca (art. 2). Gdy właściciel odsetek jest rezydentem państwa członkowskiego innego niż to, którego rezydentem jest wypłacający, jego tożsamość, nazwisko wypłacającego, numer rachunku właściciela odsetek i ich wysokość podlegają przekazaniu państwu rezydencji osoby wypłacającej.

Dyrektywa 2008/55 jest wersją skonsolidowaną dyrektywy Rady 76/308/ EWG z dnia 15 marca 1976 r. w sprawie wzajemnej pomocy przy windykacji roszczeń dotyczących niektórych opłat, ceł, podatków i innych obciążeń ${ }^{36}$. Umożliwia państwom członkowskim odzyskanie należności podatkowych powstających w innych państwach członkowskich. Stosuje się ją m.in. do: podatków od dochodów i kapitału, podatków od składek ubezpieczeniowych, a także do odsetek, kar i grzywien administracyjnych oraz kosztów ubocznych od wspomnianych wierzytelności z wyłączeniem sankcji o charakterze karnym, jak również do podatków o charakterze analogicznym do wymienionych (art. 2). Dyrektywa reguluje trzy formy współpracy: wymianę informacji, notyfikację i egzekucję należności. Informacja ta dotyczy jednak zagadnień poboru, a nie wymiaru.

\footnotetext{
34 D. Mączyński, op. cit., s. 376.

35 Dz. Urz. UE C z 2006 r., 176/8-12.

36 Dz. Urz. UE L 73/18.
} 
Wymiana informacji występuje wyłącznie na wniosek organu państwa proszącego (art. 4). Państwo winno przekazać nie tylko informacje, które posiada, lecz również wszcząć odpowiednie postępowanie, jeżeli zajdzie potrzeba ich uzyskania. Państwo proszone ma możliwość odmowy udzielenia informacji w przypadkach analogicznych do określonych w dyrektywie 77/799.

Notyfikacja dokonywana na mocy art. 5 dyrektywy 2008/55 kształtuje się analogicznie do regulacji dyrektywy 77/799. Jej celem jest jednak powiadomienie adresata o instrumentach i decyzjach, także sądowych i dotyczących wierzytelności lub jej odzyskania. Do wniosku o notyfikację dołącza się oryginał lub kopię orzeczenia lub innego dokumentu, którego dotyczy powiadomienie. Albowiem tytuł wykonawczy państwa proszącego jest traktowany jak tytuł wykonawczy państwa udzielającego pomocy (art. 8), a państwo udzielające pomocy może rozłożyć należność na raty lub odroczyć jej spłatę, jeżeli pozwala na to jego prawo krajowe lub praktyka administracyjna, po konsultacji z państwem proszącym (art. 9). Postępowanie egzekucyjne jest prowadzone na mocy przepisów prawa państwa udzielającego pomocy (art. 6). Wyjątkiem od tej reguły jest art. 12 (w przypadku kwestionowania wierzytelności lub tytułu wykonawczego ocena zasadności wniosku winna być dokonywana z punktu widzenia państwa wnioskującego).

Wierzytelności państwa proszącego nie muszą korzystać z przywilejów przysługujących wierzytelnościom państwa udzielającego pomocy, w tym przede wszystkim z pierwszeństwa ich zaspokajania ${ }^{37}$, a udzielenie pomocy zależne jest od trzech warunków: wierzytelność lub tytuł wykonawczy nie mogą być kwestionowane w państwie proszącym, chyba że pozwalają na to prawa krajowe lub praktyka administracyjna obu państw; państwo proszące bezskutecznie lub częściowo skutecznie wyczerpało procedury odzyskania wierzytelności; kwota należności (jednej lub sumy), na którą opiewa wniosek, jest wyższa niż 1500 euro.

\section{Stosunki pomiędzy Polską a Wielką Brytanią na gruncie polskiego prawa krajowego}

Na gruncie prawa polskiego istotną rolę odgrywa Rozdział VIIa dotyczący wymiany informacji pomiędzy państwami Unii Europejskiej ustawy z dnia 29 sierpnia 1997 r. Ordynacja podatkowa ${ }^{38}$. Omawiane stosunki zostały uregulowane również w ustawie z dnia 28 września 1991 r. o kontroli skarbowej39, która dopuszcza uczestnictwo przedstawicieli organów innych państw w krajowej kontroli skarbowej. Stosunki te reguluje także ustawa z dnia 17 czerwca 1966 r.

37 D. Mączyński, op. cit., s. 370.

38 T.j. Dz. U. z 2005 r. Nr 8, poz. 60 ze zm. (dalej: o.p.).

39 T.j. Dz. U. z 2004 r. Nr 8, poz. 65 ze zm. 
o postępowaniu egzekucyjnym w administracji ${ }^{40}$. Powyższe rozwiązania w większości są konsekwencją implementacji prawa unijnego ${ }^{41}$.

W polskim prawie wynikiem zastosowania procedury wzajemnego porozumiewania może być indywidualna interpretacja prawa podatkowego lub wznowienie postępowania ${ }^{42}$. Jeżeli jednak postępowanie podatkowe jest już w toku, nie ma możliwości wydania interpretacji indywidualnej prawa podatkowego i niedopuszczalne jest wówczas zawieszenie postępowania do czasu zakończenia procedury (art. 201 o.p. $)^{43}$. Zgodne z prawem jest więc wyłącznie wznowienie postępowania zakończonego decyzją ostateczną (art. $240 \S 1$ pkt 10 o.p.).

Problematyka poboru należności podatkowych została uregulowana w rozdziale 7 działu II ustawy o postępowaniu egzekucyjnym oraz rozporządzeniu Ministra Finansów z dnia 18 października 2006 r. w sprawie postępowania przy korzystaniu z pomocy obcego państwa w dochodzeniu określonych należności pieniężnych ${ }^{44}$. Warto przy tym zauważyć, że pomoc w poborze podatków w postaci notyfikacji następuje na podstawie art. 39-49 ustawy z dnia 14 czerwca $1960 \mathrm{r}$. Kodeks postępowania administracyjnego ${ }^{45}$ regulujących zagadnienia doręczeń.

Dyrektywa 2003/48 została implementowana poprzez art. 42c i 42d ustawy o podatku dochodowym od osób fizycznych oraz art. 205n-305o i 306-306n o.p. Podmiot wypłacający dochody w postaci odsetek objętych dyrektywą 2003/48 jest obowiązany przesłać sporządzone według wzoru ustalonego w rozporządzeniu Ministra Finansów z dnia 9 listopada 2007 r. w sprawie wzoru informacji o przychodach (dochodach) wypłaconych lub postawionych od dyspozycji faktycznemu albo pośredniemu odbiorcy ${ }^{46}$ imienne informacje o osobach uzyskujących te dochody: faktycznemu albo pośredniemu odbiorcy, który podlega opodatkowaniu w innym niż Polska państwie członkowskim Unii Europejskiej lub terytoriach zależnych lub stowarzyszonych Wielkiej Brytanii urzędowi skarbowemu, którym kieruje naczelnik urzędu skarbowego właściwy w sprawach opodatkowania osób zagranicznych ${ }^{47}$.

Polska zawarła umowy w sprawie opodatkowania dochodów z oszczędności osób fizycznych z następującymi terytoriami zależnymi i stowarzyszonymi Wielkiej Brytanii: Wyspami Dziewiczymi, Guernsey, Jersey, Kajmanami, Montserrat,

${ }^{40}$ T.j. Dz. U z 2005 r. Nr 229, poz. 1954 ze zm. (dalej: ustawa o postępowaniu egzekucyjnym).

${ }^{41}$ D. Mączyński, op. cit., s. 86.

${ }^{42}$ A. Kabat, A. Biegalski, Charakter prawny i stosowanie Procedury Wzajemnego Porozumiewania w międzynarodowych umowach podatkowych (art. 25 ust. 1 i 2 Modelu Konwencji OECD), „Kwartalnik Prawa Podatkowego” 2003, nr 2-3, s. 89-96.

${ }^{43}$ A. Kabat, A. Biegalski, Procedura wzajemnego porozumiewania się w świetle nowych regulacji ordynacji podatkowej, „Przegląd Prawa Podatkowego” 2005, nr 10, s. 44-45.

${ }_{44}$ Dz. U. Nr 192, poz. 1419.

${ }^{45}$ T.j. Dz. U. z 2000 r. Nr 98, poz. 1071 ze zm.

${ }^{46}$ Dz. U. Nr 212, poz. 1563.

${ }^{47}$ Rozporządzenie Ministra Finansów z dnia 22 sierpnia 2005 r. w sprawie właściwości organów podatkowych, § 5 (Dz. U. Nr 156, poz. 1371 ze zm.). 
Turks i Caicos oraz Wyspą Man ${ }^{48}$. Wzorem dla tych umów była Modelowa Konwencja o opodatkowaniu dochodów z oszczędności i automatycznej wymianie informacji w zakresie dochodów z oszczędności w formie wypłacanych odsetek, przyjęta przez Grupę Roboczą Wysokiego Szczebla Rady Ministrów Unii Europejskiej 12 marca 2004 r. $^{49}$

\section{Podsumowanie}

Nawiązanie i realizacja stosunków pomiędzy Polską a Wielką Brytanią w zakresie podatków dochodowych nie jest celem samym w sobie, lecz środkiem skutecznego wymiaru podatków i eliminacji zjawiska podwójnego opodatkowania. Brak nawiązania lub realizacji tych stosunków może umożliwić podatnikom unikanie lub uchylanie się od opodatkowania.

Dla wspomnianych stosunków niebagatelne znaczenie ma obecnie członkostwo obu państw nie tylko w OECD, ale przede wszystkim w Unii Europejskiej. Należy jednak przy tym zauważyć, że prawodawstwo unijne jest nierównomiernie rozwinięte $\mathrm{w}$ aspekcie podatków pośrednich $\mathrm{z}$ uszczerbkiem dla bezpośrednich. Dlatego też - a także z uwagi na możliwość zmiany rezydencji przez podatników, coraz częstsze dokonywanie transakcji i przepływ kapitału w wymiarze ponadpaństwowym oraz zjawisko konkurencji podatkowej pomiędzy państwami członkowskimi - harmonizacja podatków bezpośrednich powinna podlegać intensywniejszej regulacji ustawodawcy europejskiego. Przy czym należy podkreślić, że regulacje unijne wpływają również na treść umów zawieranych z terytoriami stowarzyszonymi i zależnymi Wielkiej Brytanii, określanymi mianem „rajów podatkowych", co należy oceniać niezwykle pozytywnie.

$\mathrm{Na}$ gruncie prawa krajowego analizowane stosunki podlegają realizacji nie tylko poprzez skonsolidowaną administrację podatkową, lecz także - z uwagi na zagadnienia kontroli skarbowej i egzekucji zobowiązań podatkowych - poprzez szeroko rozumianą administrację finansową.

48 Dz. U.z 2005 r.: Nr 150, poz. 1254; Nr 132, poz. 1106; Nr 143, poz. 1197; Nr 150, poz. 1256; $\mathrm{Nr} 150$, poz. 1258; Nr 150, poz. 1257; Nr 141, poz. 1180.

49 J. Fiszer, Jaki jest status umów w formie wymiany listów o opodatkowaniu oszczędności, „Gazeta Prawna”, 8 sierpnia 2008 r. 